\title{
THE INFLUENCE OF USING INSIDE - OUTSIDE CIRCLE (IOC) TECHNIQUE TOWARD STUDENTS' SPEAKING ABILITY AT THE SECOND YEAR OF MA NEGERI 1 EAST LAMPUNG
}

\author{
Septi Fitrianingsih ${ }^{1}$ \\ Lilis Sholihah ${ }^{2}$ \\ Universitas Muhammadiyah, Metro \\ Email: lilisvivo148@gmail.com
}

\begin{abstract}
One of the objectives in foreign language teaching in Indonesia is to improve speaking skill accurately and fluently. Speaking is one of difficult aspect for students to master. This is hardly surprising when one considers everything that is involved when speaking: ideas, what to say, language, how to use grammar and vocabulary pronunciation as well as listening to and reacting to the person you are communicating with. The purpose of this research is to know there is any positive and significant influence of using Inside Outside Circle (IOC) technique toward students' speaking ability at the second year students of MA Negeri 1 East Lampung academic year 2016/2017. This research is quantitative research. Research design that is used in this research is quasi experimental design. Data collecting technique of this research consists of pretest, treatment and posttest. The researcher gives test to know how far the students ability in speaking. The score of the students get from pretest and posttest. Inside Outside Circle influence the students' speaking ability. It is appropriate with the result of the students score. It was proved based on the result of $t_{\text {test }}$, where $t_{\text {count }}$ was 15,89 were higher than $t_{\text {table }}$ was 2.0 in significance level $5 \%$ and 2,66 in significance level $1 \%$. It means that there is an influence of Inside Outside Circle technique toward students speaking ability in second year of MA Negeri 1 East Lampung.
\end{abstract}

Keywords: The influence, Inside Outside Circle, Speaking ability

\section{INTRODUCTION}

One of the objectives in foreign language teaching in Indonesia is to improve speaking skill accurately and fluently. To reach the target of teaching speaking, the educational institution from secondary to higher education should implement appropriate strategies to produce good outcomes of foreign language learners. Therefore, the teaching of English on speaking skill in the classroom should be interesting and vary that can cause students to be active and enjoy learning English. Unfortunately, there are some problems of English education in Indonesia.

In learning process of speaking ability students must speak English to express their idea. In fact, many students still have problem and difficulties to speak English. In order to be able to speak English well, students have to feel comfort and confident in practicing their English. 
By feeling comfort and confident, students will not be afraid of making mistakes when speaking English. On the other hand, many students always feel uncomfortable, unconfident, and afraid of making mistakes when they are speaking English. The students are shy to speak English in front of the class because they do not master about vocabulary and grammar. Their vocabulary mastery still low make them confuse when they want to speak English.

The survey data mentions the students' speaking ability score and from the data the researcher knows the conditions of the students in the second year at MA Negeri 1 East Lampung. The percentage of low grade is $41 \%$ and percentage of very high grade only $7 \%$. The percentage of students who get high grade as much as $18 \%$ and the students who get enough grades is $34 \%$. The students who get low score are more dominant than the students who get high score. From the data above can be said that the students' speaking ability in MAN 1 Lampung Timur is still low. So, the students' speaking ability must be increased. Therefore, techique for teaching English is very important to increase student's speaking ability.

Technique is a way to achieve something. In instructional process, technique means the way to achieve the objective of learning. It is very important for instructional process to increase the students' achievement. There are many techniques that can be used to help the students in teaching learning. Inside Outside Circle is one of technique of Cooperative Learning that can use to teach speaking.
Inside - Outside Circle is one

of the cooperative learning techniques that can be applied in the speaking class. Inside-Outside Circle is a technique that gets students up and moving. It is an activity that involves all students in the class. Inside/Outside Circles are particularly useful for: differentiation, kinesthetic learners, conversation practice, and community-building in the classroom. This activity can be a great warm up as well as a useful way to change things up and get students moving during a long class (Kagan \& Miguel, 2009, p. 27).

The implementation of Inside Outside Circle technique in teaching speaking begins with the formatting of group. The students will divide into two groups. One groups forms an inside circle and the other group is outside circle. The students who face each other group will rotate one position to the left and the inside group will rotate to the right. Indirectly, they will face with a new partner. It will stop if the students have found the first partner.

Based on the description, the researcher arranges research with the title "The Influence of Using Inside Outside Circle (IOC) Technique toward Students' Speaking Ability at The Second Year of MANegeri 1 East Lampung Academic Year 2016/2017".

The objective of this research is to know there is any positive and significant influence of using Inside Outside Circle (IOC) technique toward students' speaking ability at the second year students of MA Negeri 1 East Lampung academic year 2016/2017. 


\section{RESEARCH METHOD}

Research design used in this research is quasi experimental design. Quasi experiments include assignment, but not random assignment of participants to groups, because the experimenter cannot artificially create groups for the experiment. The groups are experimental group and control group. This research conducted at MA Negeri 1 East Lampung. The researcher gives Pretest before do treatments. The researcher only gives the treatment for the experimental group. Finally, the researcher gives posttest to measure the students' speaking ability.

The population of this research is the second year students of MA Negeri 1 East Lampung Academic Year 2016/2017. There are seven classes at the second year of MA Negeri 1 East Lampung. A sample is a subgroup of the target population that the researcher plans to study for generalizing about the target population. In an ideal situation, you can select a sample of individuals who are representative of the entire population (Creswell, 2012, p. 142).

In this research, researcher takes of two classes in the second year students of MA Negeri 1 East Lampung academic year 2016/2017 as the sample. The researcher uses cluster random sampling technique. In multistage cluster sampling, the researcher chooses a sample in two or more stages because either the researchers cannot easily identify the population or the population is extremely large. If this is the case, it can be difficult to obtain a complete list of the members of the population.
Based on the explanation above, the researcher concludes that sample is part of whole and characteristic from population. In this research the researcher takes two classes of the second year of MA Negeri 1 East Lampung Academic Year 2016/2017 as the samples. Finally, XI science 1 as experimental class and XI science 3 as control class.

The instrument is as the tool of research which is used in each variable. The researcher will use speaking test to measure the result of students' speaking ability before and after treatment. The researcher gives question and oral test and analyzes the score to measure the students' speaking ability based on aspect of speaking namely pronunciation, grammar, vocabulary, fluency, and comprehension.

In this research, the researcher used construct validity and content validity. The validation was validated by two English Lecturers of Muhammadiyah University of Metro. The validators are Mr. Amirudin Latif, M.Pd and Mr. Syaifudin Latif D, S.S. M.Pd. Both of them are qualified person in English study program. The result of validation was valid because the content of the instrument was suitable with the curriculum used and it was suitable to measure students speaking ability.

In addition, the researcher used inter-rater reliability to measure the test instrument of the research. The purpose of inter rater reliability is to see the consistency of the observation result. 
The next is applying the Spearman-Brown correction formula to find the reliability test. The formula as follows:

$$
\begin{aligned}
& \mathrm{r}_{\mathrm{i}}=\frac{2 \mathrm{rb}}{1+\mathrm{rb}} \\
& \text { Notes: } \\
& \mathrm{r}_{\mathrm{i}}: \text { Reliability of } \\
& \text { Instrument } \\
& \mathrm{r}_{\mathrm{b}}: \text { the } \\
& \text { coefficient } \\
& \text { correlation between } \\
& \text { score test } \\
& 1 \& 2: \text { Constant } \\
& \text { number }
\end{aligned}
$$

Then, evaluate the result. The result of $r_{i}$ consulted to the criteria of reliability as follows:

Reliability coefficient:

1. A very high reliability ranges from 0.81 up to 1.00

2. A high reliability ranges from 0.61 up to 0.80

3. Average reliability ranges from 0.41 up to 0.60

4. Low reliability ranges from 0,21 up to 0,40

5. A very low reliability rages from 0.00 up to 0.20

(Adopted from Sugiyono, 2010, p. 185)

The most important step in conducting the research is collecting data. In collecting the data, the researcher used test as the data collecting technique. The test was conducted two times they were pretest and posttest. The researcher did the treatment as much as 2 times. The test that had been given as follows: A pretest provides a measure on some attribute or characteristic that you assess for participants in an experiment before they receive a treatment (Creswell, 2012 , p. 297). The test is the main technique in collecting data. The test is used to get the data about students' speaking ability. This step do before presenting the treatment to know how far the influence using Inside Outside Circle technique. Pretest had been administered to both experimental and control class. The aim of pretest is to know the students' progress. The teacher provides some topics. After pretest researcher give treatment for the students. The researcher applied Inside Outside circle technique for experimental class in the instructional process. For control class, the researcher used technique same as the teacher while teaching the students. After treatment, the researcher gave posttest in the next meeting. Based on syllabus of second year at senior high school the material that will be taken by researcher is about asking and giving opinion. A posttest is a measure on some attribute or characteristic that is assessed for participants in an experiment after a treatment (Creswell, 2012, p. 297). The instrument of posttest is equivalent with Pretest. The researcher give the test for experimental and control class. The aim of posttest is to know the students' progress after given the Inside Outside Circle (IOC) Technique in learning English especially in their speaking ability. Posttest score then has been compared to determine the effectiveness of this treatment.

Then, the researcher uses $\mathrm{T}$ test formula includes the normality test, homogeneity test, and hypothesis test. The purpose of normality test is to know whether data distribution is normal or not. In 
statistic, normality test is used to determine whether the data set is well modeled by a normal distribution or not.

In conclusion, statistic hypothesis is an assumption about a population parameter. This assumption may or may not be true. If samples data are not consistent with the statistical hypothesis, the hypothesis is rejected, because test is used to know whether the hypothesis that is proposed can be accepted or rejected.

\section{RESULT AND DISCUSSION}

In this research, the researcher used construct validity and content validity. The instrument was validated by two English Lecturers of Muhammadiyah University of Metro. The valuators are $\mathrm{Mr}$. Amirudin Latif, M.Pd and Mr. syaifudin Latif D, S.S. M.Pd. Both of them are qualified in English departmet. The result of validation was valid because the content of the instrument was suitable with the curriculum used and it was suitable for measure students speaking ability.

In this research, the researcher counted the result of reliability test by using Product Moment Formula. After Calculating, it was gotten 0,99 that meant the reliability is very high. So, the instrument was reliable and could be used for the testing hypothesis in this research.

In collecting data, the researcher used the test. The researcher gave pretest before giving the treatments. The researcher administered the pretest for experimental class and for control class.

The researcher gave treatment to the students in experimental class by using Inside Outside Circle Technique. In the learning process, the use of method was very easy, because all of students could follow the class very well. The students could improve their ability in speaking by applying this method. The students followed the learning process very enthusiastically and do the assignment very well.

The researcher gave the posttest after giving treatments in two meetings in the experimental class. The posttest was given in experimental class and control class in order to know the students' speaking ability after the students got the treatments. The posttest instrument has same criteria with the pretest instrument.

The normality test was conducted to know whether the both of data classes were normal distribution or not. The data is supposed to be normal if $x_{\text {count }}^{2} \leq x_{\text {table }}^{2}$ at the significance level 0,05 and 0,01 . To know the normality of the data, the researcher used Chi Square formula. The result of normality of experimental class is 1,74 and for experimental class is 3,13 . It means that $x_{\text {count }}^{2}$ is lower than $x_{\text {table }}^{2}$, so this research is has normal distribution.

The data homogeneity of the test accepted $\mathrm{H}_{\mathrm{o}}$ if $\mathrm{F}_{\text {count }} \leq \mathrm{F}_{\text {tablefor }}$ significance level $5 \%(\alpha=0,05)$ and also the significance level $1 \%$ $(\alpha=0,01)$. The result of homogeneity test is 0,35 it means that $F_{\text {count }} \leq F_{\text {table. }}$. So, $\mathrm{H}_{\mathrm{o}}$ is accepted or in other word 
both of population had same variance or homogeneous.

The result of criteria of the hypothesis above, the researcher found that $\mathrm{t}$-count $=15,89$ moreover the researcher looked at $\mathrm{t}$-table for $\alpha=5 \%$ t-table $=2,00$ and for $\alpha=1 \% \mathrm{t}$ table $=2,66$ or it means $\mathrm{t}$-count $\geq \mathrm{t}$ table. It means that Inside Outside Circle gave positive influence to improve students speaking ability at second year students of MA Negeri 1 East Lampung.

\section{DISCUSSION}

The purpose of this research is to know the influence of Inside Outside Circle toward students speaking ability. The data that the researcher got from experimental and control class show there is different result between pretest and posttest score in experimental class and control class. In more detail, the change of students' posttest score is higher than pretest score especially in experimental class which use Inside Outside Circle Technique. Insideoutside circle is a technique which is introduced by Spencer Kagan (Lie, 2008, p. 65). In experiment class, student could enjoy, active, confident and be more interested in learning English especially in speaking. It can be seen in gain of the students' score. The highest score in pretest was 82 and the lowest score was 54, but after getting treatment the score changed become the highest was 84 and the lowest was 68 in posttest. It was very good progression from students.

In conclusion, the students speaking ability was good enough, because after getting treatment and doing the posttest the researcher can be concluded that many students were passing from the standard minimum score, it can be concluded that there is positive and significance influence of Inside Outside Circle (IOC) technique toward students speaking ability.

\section{CONCLUSION}

Inside Outside Circle technique can cause better activity in the learning process of the students. It also makes the students' speaking ability better than before. Based on the posttest, the researcher can take the conclusion that the students' score of speaking ability was increased. Because it can be seen from the experimental class' score was the highest one, it was 84 and the lowest score was 68 . This result could be concluded that the score was very good. Activity of the students is influenced by Inside Outside Circle Technique and also it affected the students' speaking ability. It was proved based on the result of t-test where t-count was 15,89 was higher than t-table 2,0 in significant level $5 \%$ and 2,66 in significant level $1 \%$. It means that there is positive and significance influence of Inside Outside Circle (IOC) technique toward students' speaking ability at second year of MA Negeri 1 East Lampung.

\section{SUGGESTION}

Hopefully, this research will be beneficial for the students, English teacher and other researcher. The students can invite their friends to practice Inside-Outside Circle themselves. The students can practice it every day in the class. So they are not bored when they are in the class. Moreover, the English 
teacher should implement this interesting technique in speaking class. It has been known that the use of Inside Outside Circle (IOC) can improve the students' speaking ability, so that the other researchers or the readers can investigate the same research for teaching speaking with the same or different method of research.

\section{REFERENCES}

Brown, H. D. (2004). Principles and Classroom Practices. New York: Pearson Education,Inc. (2007). Principles of Language Learning and Teaching. San Francisco: United States of America.

Clark, H. H., \& Clark, E. V. (1997). Psychology and Language: an Introduction to Psycolinguistic. New York: Harcourt Brace Jovanovich Publishers.

Creswell, J. W. (2012). Educational Research: Planning, Conducting, and Evaluating Quantitative and Qualitative Research. Boston: Pearson Education.

Kagan, S., \& Miguel, K. (2009). Cooperative Learning. San Clemente: Kagan Publishing.

Lie, A. (2008). Cooperative Learning: Mempraktikkan Cooperative Learning di Ruang-ruang Kelas. Jakarta: Grasindo.
Spratt, M. P., \& William, M. (2005). The TKT Course. Cambridge: University Press.

Sudrajad, M., \& Wijaya, A. (2016). The Effectiveness of InsideOutside Circle Method by Using Cue Card for Students' Speaking Ability at Seventh Graders. Journal of English Educators Society (JEES): 59-70.

Sugiyono, P. D. (2010). Metode Penelitian Pendidikan Pendekatan Kuantitatif, Kualitatif, dan $R \& D$. Bandung: Alfabeta. 